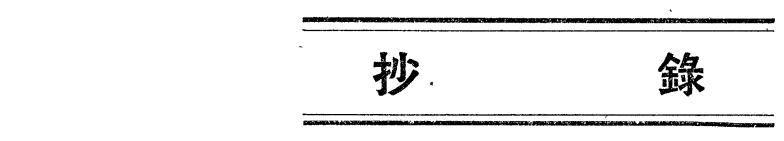

燃 燒

U.D.C. 662.61

\section{燃燒排ガス中における $\mathrm{SO}_{3}$ の生成}

(T. Wide11, Combustion, 24, No. 12, 53 (1953))

然料中のSが然燒によつて $\mathrm{SO}_{2}$ にり,さらに, こ れがSO 3 になる機構については HarlowとWhittingham の相反する說がある。すなおち Harlow による と, 過熱器の表面で, 比較的低溫度で $\mathrm{SO}_{3}$ 一の酸化が 起るといい, Whittingham によると, 比較的高溫な 焰の中で, 原子状の酸素によって $\mathrm{SO}_{2}$ が酸化されて, $: \mathrm{SO}_{3}$ が生成する。これを検討するため, 燃料重油中の $\mathrm{S} 2.25 \%, 25 \%$ 過剩空気の場合，平衡のときの $\mathrm{SO}_{3}$ 量 を算出し，さらに一定溫度に和ける $\mathrm{SO}_{3}$ 生成に及位す 時問之燃燒の速度の影響扣よび然燒の過程に和ける溫 度変化の状態老求め, これから $100^{\circ} \mathrm{C}$ 以上の溫度で $: \mathrm{SO}_{3}$ が最高を示すとてろがあり，てれは低溫度でボイ ラの伝熱面が触媒として㗢くといらょりはむしろ， $: \mathrm{SO}_{3}$ が焰中で生成するといら Whittingham の榄を 裏付けるものである。(山田)

\section{液 体 蹨 料}

U.D.C. 662.75

\section{重油一軽油の調合安定度}

(D. G. Bultin, J. Inst. Petr., 39, 294(1953))

同誌 36, 43 (1950) に報告されたものの続報で調合 安定度をアニリン点と表面張力から解析している。報 告は 3 節にわかれ，

（1） キシレン当量测定法の改良

調合安定度の指針として测定されるキシレン当量は 前報ではホワイトスピリットを佒つているが本報では nーヘキサン，n-ヘプタン，イソオクタン，n-セタンの 4 純炭化水素を㑛つた。セタンஙガス油の溜分に入る ので注目されるものであるが，骶点の高いととと揮発 性がキシレンとはなはだ違らためで適当でない。反対 の意味でnーヘキサンも適当でなく，イソオクタンなた はヘプタンがよい。試験時間忙 $24 \mathrm{hr}$ から 2 3hrk短 縮できる。6 種の重油について前記各パラフィンによ
るキシレン当量と混合物のアンリン点, 表面張力を湖 定した。

(2) 重油に対する轻油の適合性をアニリン点で制 断するととの可否 前瓣でも述べているように調合安 定度々アンリン点だけでは制断できない。すなおち， 同じアニリン点を有する 2 種の軽油を調合するとスラ ッジの生成量は必ずしも同じでなく非常に違う場合が ある。これは軽油の表面張力に関連すると涍えられる。 キシレンと前述のパラフィン炭化水素の备割合の混合 物のアニリン点と裴面張力を测定した。

試料の重油についてパラフィン炭化水素を变えてキ シレン当量を測定し, 当量の場合の稀釈油のアニリン 点と表面張力との関係洞一重油についてい直線的に なる。アニリン点が高ければ表面張力名大で, 表面能 力1dyne/cm についての倾斜は ${ }^{\circ} \mathrm{F} て ゙$ 裴わして最大 9.6 最小 6.4 で 6 種の本均注 7.5 であつた。

（3）柽油を調合する場合へのアニリン点と表面張 力の関你の応用 そとえばアニリン点がいずれも 120 ${ }^{\circ} \mathrm{C}$ の 2 䅡の柽油老調合すると表面張力 30.1 dyne $/ \mathrm{cm}$ でスラッジが $0.65 \%$ に対し 27.4 dyne/cm のbので は $2.75 \%$ Кなる例がある。

2 節のアンリン点と表面張力の関係を㨁ちに空用す るととは危険であるが，ホワイトスピリットを作つて も同じ直線関係になるので大体適用できるであるう。 そのために, イソォクタンーキシレン, nーヘプタン一 キシレンの混合物のアニリン点一表面張力図表を作つ た。

たとえばイソォクタンによるキシレン当量 44 の重油 については, 図表より当量のキシレンーイソォクタン 混合油のアニリン点, 表面張力ね $84^{\circ} \mathrm{F}, 21.6 \mathrm{dyne} / \mathrm{cm}$ でキシレン当量の定義からてれが安定調合できる限度 である。第 2 節の結果からいつて表面張力 $1 \mathrm{dyne} / \mathrm{cm}$ 上景につき，アニリン点は最低 $6^{\circ} \mathrm{F}$ 上昇が許される から,調合ガス油の表面張力を测定すれば, 21.6dyne/ $\mathrm{cm}$ との差から訢容最高アニリン点が求められる。と れが実测アニリン点より高ければ調合可能，低くけれ ば不能であつて，6種の軽油について实例をあげてあ るが, 定性的にはもちろんほぼ定量的にアニリン点差 と生成スラッジ量が関你づけられている。 な和キシレン当量测定法が附記されている。(小林) 